\title{
REPERTORIO BIBLIOGRÁFICO SOBRE CONTROL PARLAMENTARIO
}

\author{
FRANCISCO MARTÍNEZ VÁZQUEZ \\ Letrado de las Cortes Generales
}

\section{NOTA PRELIMINAR}

Una pequeña obra de Balzac ${ }^{1}$ cargada de reflexiones sensatas fue capaz de expresar el sentimiento de frustración que necesariamente acompaña la ejecución de cualquier empresa intelectual emprendida con ilusión, hasta tal extremo que es posible advertir la existencia de una relación de proporción inversa entre el entusiasmo invertido y la frustración aparecida como inevitable secuela. Si toda obra humana es, por definición, eternamente perfectible, con mayor razón lo será cualquier intento de sintetizar las principales aportaciones científicas realizadas sobre una materia concreta. Sin pretender con estas palabras una inmerecida indulgencia por aquellas omisiones que, sin duda, atenúan la calidad del trabajo recogido en las páginas siguientes, sí me permito comenzar esta nota con una disculpa hacia todos aquellos autores que han tratado el tema del control parlamentario y cuyas obras merecen figurar en esta síntesis de las principales aportaciones en lengua española sobre la materia. Su ausencia es imputable única y exclusivamente al desconocimiento u olvido del autor de este repertorio.

Continuando en el terreno de las aclaraciones previas - que no excusas-, me siento en la obligación de poner de manifiesto algunas restricciones que forzosamente han servido como premisa metodológica en la elaboración de este repertorio:

En primer lugar, es evidente que una materia como el control parlamentario se relaciona directamente con numerosos aspectos esenciales de la Teoría del Estado, en la medida en que la forma de articularse en los distintos sistemas constitucionales el ejercicio de la función de control determina, en primera instancia, la adscripción a alguna de las categorías tipológicas en que se clasifican tradicionalmente las formas de gobierno, sin perjuicio de que estas categorías

1 H. DE BALZAC, La obra maestra desconocida, 1831.

UNED. Teoría y Realidad Constitucional, núm. 19, 2007, pp. 415-439. 
sean más propias del discurso teórico y queden desbordadas en la práctica política. Sin embargo, no podemos obviar que el origen de la distinción entre los sistemas de gobierno presidencialistas, parlamentarios y de asamblea está íntimamente relacionado con el modo de articularse la convivencia entre el Poder Legislativo y el Poder Ejecutivo, todo lo cual guarda una estrechísima relación con el alcance y limites de la función de control parlamentario.

Aparece así la primera limitación a la que hacíamos referencia, pues desde el punto de vista metodológico no se han incluido en el presente repertorio las innumerables obras de carácter general que abordan el control parlamentario en el seno de un discurso más amplio, enfocado desde el prisma de la Teoría del Estado, la Teoría Política, la Ciencia Política, el Derecho Constitucional. La razón de esta exclusión es esencialmente de orden práctico, pues pretender agotar en un solo repertorio bibliográfico el amplio conjunto de obras que se refieren tangencialmente a esta materia sería una empresa inabarcable por su dimensión. Por esta razón, hemos limitado la relación de obras incluida en las páginas sucesivas a aquellas que podemos adscribir al ámbito específico del Derecho Parlamentario, sin olvidar las particularidades de esta rama del ordenamiento jurídico y su natural relación con el Derecho Constitucional, hábilmente sintetizada por Tosi al definir esta disciplina como una "clinica constitucional.

La segunda limitación se refiere al idioma de las obras incluidas en el presente repertorio ya que, por las mismas razones prácticas a las que antes hemos aludido, resulta imposible recoger en un solo documento las principales aportaciones de la literatura científica sobre control parlamentario en varias lenguas. En efecto, la riqueza del Derecho comparado en este ámbito es digna de destacar, pero convierte en una empresa demasiado ambiciosa la recopilación de la variedad de tratados, monografías, artículos científicos, etc., escritos en lenguas distintas del español. Por esta razón, el repertorio bibliográfico incluye muy pocas referencias a obras escritas en otros idiomas, limitándose a aquellas que, por diversas razones, resultan especialmente dignas de mención, pero sin pretender con ello agotar las fuentes existentes en otras leguas que merecerían, sin duda, la elaboración de un repertorio específico.

En tercer lugar, debemos reconocer que las distintas referencias bibliográficas se centran en los aspectos actuales del control parlamentario, toda vez que el análisis histórico es también enormemente rico en esta materia pero ha sido reflejado de manera más limitada, con cita de obras relevantes que aluden específicamente a la Historia del parlamentarismo español pero, una vez más, sin pretensión de exhaustividad. Aparece aquí otra renuncia forzosa en la elaboración del repertorio, justificada por el imperativo de concretar las referencias al ámbito específico de estudio de una publicación científica sobre Derecho Constitucional, que no puede perder de vista la influencia decisiva de la Historia del Constitucionalismo, pero tampoco consagrarse de lleno a su estudio.

Hechas estas advertencias, parece conveniente justificar también el esquema seguido en la ordenación de las distintas obras incluidas en el repertorio. Desde esta perspectiva, debemos subrayar que el primer apartado está dedi- 
cado a la que podríamos denominar Teoría general del control parlamentario, pues bajo este epígrafe se incluyen todas aquellas obras, monografías o artículos que hacen referencia a la función de control en su conjunto, a su definición constitucional, a su fundamento político o al análisis comparado de las distintas instituciones e instrumentos.

En la presentación de las principales referencias bibliográficas en esta materia, hemos pretendido incluir aquellas reflexiones que enfrentan el concepto de control parlamentario vigente tras los cambios políticos producidos por la II Posguerra Mundial y la eclosión de lo que García Pelayo denominó el Estado de partidos. En esta línea, parece importante acoger esa visión multifuncional de los procedimientos parlamentarios que propone Rubio Llorente y abordar una reflexión madura y actual de las funciones del Parlamento como órgano de resonancia pública — según la expresión de Burdeau—, en definitiva, como "casa de la oposición", todo ello como consecuencia de la trascendental novedad que supuso en el funcionamiento de la forma de gobierno parlamentaria esa "unión hipostática" entre el Gobierno y la mayoría parlamentaria provocada por la dinámica partidista.

En este mismo apartado, se incluyen las obras que abordan el control parlamentario desde una perspectiva histórica y también aquellas que analizan aspectos de la función de control que no tienen un encaje claro en el resto de rúbricas en que se divide el presente repertorio.

El segundo apartado está dedicado a recopilar aquellas aportaciones bibliográficas que analizan la esencia de la función de control, es decir, las que abordan los instrumentos de otorgamiento y retirada de la confianza parlamentaria. Es evidente que la regulación constitucional de la investidura y la moción de censura, como engranaje fundamental del sistema parlamentario, se analiza en todas las obras generales de Derecho Constitucional (tratados, manuales, etc.) si bien hemos pretendido reducir la relación a aquellas obras que se centran de manera monográfica o específica en estos instrumentos del parlamentarismo.

En tercer lugar, dedicamos un epígrafe específico a analizar los instrumentos de control más extendidos en el parlamentarismo racionalizado como son las preguntas y las interpelaciones parlamentarias. La consideración del Parlamento como institución cuya función última y básica es proporcionar status jurídico-constitucional a la oposición política y servir como centro institucional articulador de la libre competencia por el poder convierte estos instrumentos de control directo en una pieza clave de las democracias contemporáneas, con especial capacidad de influencia en la opinión pública, gracias a la publicidad que proporcionan los medios de comunicación social, especialmente en el caso de las sesiones de question time.

Un epígrafe específico está dedicado al análisis de la bibliografía existente sobre comisiones de investigación, sin duda uno de los instrumentos de control parlamentario de mayor importancia en el parlamentarismo contemporáneo, a juzgar por el número de obras dedicadas monográficamente a su análisis. La configuración asintótica de la investigación parlamentaria con la investigación judicial sobre hechos que producen especial alarma social, la necesaria afecta- 
ción de derechos fundamentales en la regulación de las comparecencias ante dichas comisiones, los límites derivados de la clasificación de las materias sobre las que versa la investigación parlamentaria y, sobre todo, el hecho notorio de que el trabajo de estos órganos carece de esa pauta directiva que ejerce el Gobierno sobre el resto de las funciones parlamentarias, en particular, sobre la función legislativa, hacen de las comisiones de investigación un instrumento de extraordinario interés para el Derecho Parlamentario contemporáneo.

El apartado quinto del repertorio bibliográfico aborda de manera conjunta aquellos instrumentos que protagonizan el debate doctrinal acerca de la distinción entre los instrumentos de información parlamentaria y los instrumentos de control. Hacemos referencia, por tanto, a la bibliografía sobre las comparecencias, solicitudes de informes y documentos y otra serie de instrumentos cuya adscripción a la función de control o a la función informativa no deja de ser, en muchos caso, un debate teórico pues es evidente, como destacó De Vergottini, que la función informativa tiene una naturaleza polivalente que permite su configuración en muchos casos como un instrumento de inspección parlamentaria dotado de un evidente carácter coercitivo.

La importancia del control parlamentario sobre determinados aspectos estratégicos de la gestión política aconseja dedicar un apartado específico al análisis de las especialidades que presenta la función de control cuando recae sobre materias tan sensibles como los secretos oficiales, gastos reservados 0 cuestiones relativas a la política exterior y a la política de defensa. Las democracias contemporáneas se caracterizan por la saludable tendencia a extender el alcance del control parlamentario a cualquier acción del Gobierno, por reservada que ésta pudiera resultar, todo lo cual explica que se adopten mecanismos especialmente cualificados para salvaguardar los restantes valores constitucionales que se ven implicados en estas formas de control.

En última instancia la abundancia de obras que abordan de manera específica el desarrollo de la función de control parlamentario en el ámbito de las Comunidades Autónomas exigía un tratamiento diferenciado de las mismas en el último de los apartados de este repertorio. Es sobradamente conocido que la Constitución Española no pudo definir de manera agotadora el sistema de gobierno de las distintas Comunidades Autónomas y que la virtualidad del artículo 152 como regla de homogeneidad institucional es ciertamente limitada y habría permitido distintos modelos políticos, con exclusión de los más extremos (presidencialismo puro o forma de gobierno asamblearia). Sin embargo, la tentación mimética siempre presente en la configuración institucional de los sistemas autonómicos, por más que se reivindique permanentemente la diferencia, ha llevado a la implantación en todos ellos de formas de gobierno de corte parlamentario inspiradas en el diseño constitucional del conjunto del Estado. Esta misma tendencia mimética explica la presencia de instrumentos de control parlamentario en los ordenamientos jurídicos autonómicos que son fiel reflejo de los existentes en el ámbito de las Cortes Generales, a pesar de lo cual no debemos dejar pasar inadvertidas algunas singularidades que han merecido el análisis de la doctrina científica. 
SUMARIO

1. El control parlamentario: teoría general, evolución histórica y Derecho comparado.

2. Otorgamiento y retirada de la confianza parlamentaria: investidura, cuestión de confianza, moción de censura.

3. Instrumentos de control parlamentario (I): las preguntas y las interpelaciones parlamentarias.

4. Instrumentos de control parlamentario (II): las comisiones de investigación parlamentaria.

5. Instrumentos de control parlamentario (III): comparecencias ante las Cámaras y solicitudes de información y documentación.

6. Especialidades del control parlamentario: el control parlamentario sobre materias clasificadas y gastos reservados y sobre la política exterior y la política de defensa.

7. El control parlamentario en las Comunidades Autónomas.

\section{EL CONTROL PARLAMENTARIO: TEORÍA GENERAL, EVOLUCIÓN HISTÓRICA Y DERECHO COMPARADO}

ACOSTA RAMÍREZ, Francisco: "El Senado de la Restauración como Cámara de control: su protagonismo en el siglo xx", Comisión Internacional para el Estudio de la Historia de las Instituciones Representativas y Parlamentaria, actas del 47 Congreso, Joseba Agirreazkuenaga y Mikel Urquijo (ed.), Juntas Generales de Bizkaia, Bilbao, 1999, págs. 797-815.

AGUIAR DE LUQUE, Luis: "La problemática del control en la actualidad", en $E l$ parlamento a debate, Trotta, Madrid, 1997, págs. 93-107.

ALFONSO GIL, Javier: "Notas sobre la nacionalización y el control parlamentario de la empresa pública", Hacienda Pública Española, n. ${ }^{\circ}$ 89, 1984.

ÁLVAREZ CONDE, Enrique: "Las funciones de control político", Curso de Derecho Constitucional, Tecnos, Madrid, 1992-1993, Vol. 2, págs. 152-185.

ÁLVAREZ-OSSORIO MICHEO, Fernando: "El adecuado control parlamentario", Revista Española de Derecho Constitucional, n. ${ }^{\circ}$ 43, 1995.

- "Suspensión individual de garantías, adecuado control parlamentario y tiempo (artículo 55.2 CE)", en La defensa del Estado: actas del I Congreso de la Asociación de Constitucionalistas de España, Eduardo Espín Templado y Luis María López Guerra (coords.), Tirant lo Blanch, Valencia, 2004, págs. 247-256. 
ANTONAYA SUJA, Ángel Luis: "Consideraciones críticas sobre el control parlamentario" en Control del sector público, Instituto de Estudios Fiscales, Madrid, 1981, págs. 93-111.

ARAGÓN REYES, Manuel: "El control parlamentario”, Revista de Derecho Politico, n. ${ }^{\circ} 23,1986$.

- "El control parlamentario como control político", en Estudios en homenaje al doctor Héctor Fix-Zamudio en sus treinta años como investigador de las Ciencias Jurídicas, Universidad Nacional Autónoma, Instituto de Investigaciones Jurídicas, México, 1988, págs. 3-35.

- Gobierno y Cortes, Instituto de Estudios Económicos, Madrid, 1994.

- Constitución y control del poder: introducción a una teoría constitucional del control, Ciudad Argentina, Buenos Aires, 1995.

- "Sistema parlamentario, sistema presidencialista y dinámica entre los poderes del Estado: análisis comparado", en Parlamento y control del Gobierno: V Jornadas de la Asociación Española de Letrados de Parlamentos, Francesc Pau i Vall (coord.), Aranzadi, Pamplona, 1998, págs. 29-45.

ARRATÍBEL ARRONDO, José Antonio: “El control parlamentario de la actividad económica del sector público vasco: características del sistema jurídico general y foral", Auditoría pública: revista de los Órganos Autónomos de Control Externo, n. ${ }^{\circ} 38,2006$, págs. 51-64.

ARREGUI MINCHERO, Blanca: «El control de las corporaciones locales desde el ámbito parlamentario", Análisis local, n. ${ }^{\circ} 49,2003$, págs. 59-70.

ARROYO DOMÍNGUEZ, Jesús: "Apuntes sobre la proposición no de ley: concepto y práctica parlamentaria", Corts. Anuario de Derecho Parlamentario, n. ${ }^{\circ} 16,2005$.

BARBERÁN LÓPEZ, José Manuel: "Control parlamentario y Tribunal de Cuentas", en Problemas actuales del control parlamentario: VI Jornadas de Derecho Parlamentario, Congreso de los Diputados, Madrid, 1997, págs. 87-100.

BARÓN, Enrique: "El control parlamentario”, en Control del sector público, Instituto de Estudios Fiscales, Madrid, 1981, págs. 77-91.

BOSCH BENÍTEZ, Óscar: «Dos supuestos de control político-parlamentario: la Comisión de Control de Radio y Televisión (RTVE) del Congreso de los Diputados y su variante autonómica canaria", Revista canaria de Administración Pública, n. ${ }^{\circ}$ 3, 1989.

BLANCO VALDES, Roberto L.: "Acción del Gobierno, política de nombramientos y control parlamentario", Documentación Administrativa, n. ${ }^{\circ}$ 246-247, 1997.

- "Altos cargos y control parlamentario", Claves de Razón Práctica, n. ${ }^{\circ} 82$, 1998.

BREWER-CARIAS, Allan R.: "Aspectos del control parlamentario sobre la Administración Pública nacional en Venezuela", Revista de Administración Pública, n. ${ }^{\circ}$ 92, 1980.

CAVERO GÓMEZ, Manuel: "Control parlamentario y Poder Judicial", en Problemas actuales del control parlamentario: VI Jornadas de Derecho Parlamentario, Congreso de los Diputados, Madrid, 1997, págs. 65-86. 
CONTRERAS CASADO, Manuel: "Crónicas de las III Jornadas Internacionales de Ciencia Política y Derecho Constitucional. El control parlamentario del Gobierno en las Democracias pluralistas", Revista de Estudios Políticos, n. ${ }^{\circ} 3$, 1978.

DE CARO, Carmela: "Control parlamentario del Ejecutivo. Italia" en Democracia representativa y parlamentarismo: Alemania, España, Gran Bretaña e Italia. Jornadas de Derecho Constitucional Comparado, Antonio López Pina (dir.), Senado, Madrid, 1994, págs.233-267.

DE LA CRUZ FERRER, Juan: «El control parlamentario de la Administración en el sistema constitucional norteamericano", en I Jornadas de Derecho Parlamentario, Congreso de los Diputados, Madrid, 1985, vol. 2, págs. 963-987.

DE LA PEÑA RODRÍGUEZ, Luis: «El control parlamentario del Gobierno en funciones a la luz de la Constitución", en Parlamento y control del Gobierno: $V$ Jornadas de la Asociación Española de Letrados de Parlamentos, Francesc Pau i Vall (coord.), Aranzadi, Pamplona, 1998, págs. 345-350.

- "La función de control en la jurisprudencia constitucional" en Parlamento y justicia constitucional: IV Jornadas de la Asociación Española de Letrados de Parlamentos, Francesc Pau i Vall (coord.), Aranzadi, Pamplona, 1997, págs. 517-556.

- "El control parlamentario: debates generales y monográficos", en El reglamento parlamentario: propuestas de reforma, Luis María Corona Ferrero, Marta E. Souto Galván, Ángel L. Sanz Pérez (coords.), Parlamento de Cantabria, Santander, 2000, págs. 385-412.

EMBID IRUJO, Antonio: «El control parlamentario del Gobierno y el principio de la mayoría parlamentaria. Algunas reflexiones", Revista de las Cortes Generales, n. ${ }^{\circ} 25,1992$.

- «El control parlamentario del Gobierno en la jurisprudencia del Tribunal Constitucional", Revista Vasca de Administración Pública, Herri-Arduralaritzako Euskal Aldizkaria, n. ${ }^{\circ} 44,1,1996$, págs. 153-169.

ELVIRA PERALES, Ascensión y GONZÁLEZ AYALA, María Dolores: "Las decisiones extraparlamentarias condicionantes de la función legislativa", en $E l$ procedimiento legislativo: V Jornadas de Derecho Parlamentario, José Luis Peñaranda Ramos (coord.), Congreso de los Diputados, Madrid, 1997, págs. 35-60.

FERNÁNDEZ DE SIMÓN BERMEJO, Encarna: «El control parlamentario y la opinión pública" en Parlamento y opinión pública, Francesc Pau i Vall (coord.), Tecnos, Madrid, 1995, págs. 191-195.

FERNÁNDEZ MARUGÁN, Francisco: «El presupuesto hoy: límites, transparencia y control parlamentario", Sistema: Revista de Ciencias Sociales, n. ${ }^{173,}$ 2003, págs. 15-30.

FERNÁNDEZ SARASOLA, Ignacio: «El control parlamentario y su regulación en el ordenamiento español", Revista Española de Derecho Constitucional, n. ${ }^{\circ}$ 60, 2000.

- Poder y libertad: los orígenes de la responsabilidad del Ejecutivo en España, (1808-1823), Centro de Estudios Políticos y Constitucionales, Madrid, 2001. 
FONSECA GARCÍA-DONAS, Javier: "La responsabilidad criminal del presidente del Gobierno: las posibles consecuencias políticas del artículos (i.e. artículo) 102.2 de la Constitución", en Homenaje a D. Iñigo Cavero Lataillade, José Peña González (dir.), Tirant lo Blanch, Valencia, 2005, págs. 245-260. GARCÍA-ESCUDERO MÁRQUEZ, Piedad y PENDÁS GARCÍA, Benigno: «Senado y Gobierno: el Senado como Cámara de control" en Gobierno y Administración en la Constitución, Instituto de Estudios Fiscales, Madrid, 1988, vol. I, págs. 659-674.

GARCÍA FERNÁNDEZ, Javier: «El control parlamentario desde la perspectiva del Gobierno", Cuadernos de Derecho Público, n. ${ }^{\circ}$ 2, 1997.

- "Funciones de control del Parlamento sobre el Gobierno", en El poder legislativo en la actualidad, Cámara de Diputados del H. Congreso de la Unión, México, 1994, págs.37-54.

GARCÍA HERRERA, Miguel Ángel: "Mayoría y minoría y control parlamentario" en Problemas actuales del control parlamentario: VIJornadas de Derecho Parlamentario, Congreso de los Diputados, Madrid, 1997, págs. 197-224.

GARCÍA MARTÍNEZ, María Asunción: "La actividad legislativa del Parlamento como mecanismo de control político", Revista de las Cortes Generales, n. ${ }^{\circ}$ 14, 1988.

GARCÍA MORILLO, Joaquín: El control parlamentario del Gobierno en el ordenamiento español, Congreso de los Diputados, Madrid, 1985.

- "Aproximación a un concepto del control parlamentario", Revista de la Facultad de Derecho de la Universidad Complutense, n. ${ }^{\circ}$ 10, 1986.

- "Algunos aspectos del control parlamentario" en El Parlamento y sus transformaciones actuales: jornadas organizadas por la Asamblea Regional de Murcia (11-13 de abril de 1988), Angel Garrorena Morales (dir.), Tecnos, Madrid, 1990, págs. 247-252.

GARCÍA ROCA, Javier: «El control del Gobierno desde la perspectiva individual del Parlamentario (y a la luz del art. 23.2 de la Constitución)", Revista Vasca de Administración Pública, n. ${ }^{\circ}$ 42, 1995.

- "La fragilidad de los ministros (de su competencia y responsabilidad directas)", en Gobierno y Constitución: actas del II Congreso de la Asociación de Constitucionalistas de España, Pablo Lucas Murillo de la Cueva (coord.), Tirant lo Blanch, Valencia, 2005, págs. 153-207.

GARCÍA SORIANO, María Vicenta: “Utilización de la legislación delegada y su control parlamentario: Aplicación durante el periodo 1989-1994", en Problemas actuales del control parlamentario: VIJornadas de Derecho Parlamentario, Congreso de los Diputados, Madrid, 1997, págs. 893-916.

GIL-ROBLES y GIL-DELGADO, José María: "Naturaleza jurídica del control sobre el Gobierno y la Administración" en Gobierno y Administración en la Constitución, Instituto de Estudios Fiscales, Madrid, 1988, vol. I, págs. 729-762.

- "El Defensor del Pueblo y el control parlamentario de la Administración", Anales de Derecho, n. ${ }^{\circ}$ 10, 1987-1990, págs. 193-206.

GÓMEZ CORONA, Esperanza: "Control parlamentario, minorías y Tribunal Constitucional" en El Parlamento del siglo XXI, VIII Jornadas de la Asocia- 
ción Española de Letrados de Parlamentos, Francesc Pau i Vall (coord.), Tecnos, Barcelona, 2002, págs. 77-88.

GONZÁLEZ ALONSO, Alicia: "El Gobierno en funciones”, en El Gobierno: problemas constitucionales, Manuel Aragón Reyes, Ángel J. Gómez Montoro (coords.), Centro de Estudios Políticos y Constitucionales, Madrid, 2005, págs. 513-560.

GONZÁLEZ TREVIJANO, Pedro José: “De nuevo sobre el control parlamentario: una propuesta de teoría general" en Estudios de Derecho Constitucional: bomenaje al profesor Dr. D. Joaquín García Morillo, Luis López Guerra (coord.), Tirant lo Blanch, Valencia, 2001, págs. 345-369.

GONZALO, Manuel: "La publicidad en los debates de control parlamentario", en Parlamento y opinión pública, Francesc Pau i Vall (coord.), Tecnos, Madrid, 1995, págs. 197-202.

GUERRERO, Enrique: "La actualidad del control parlamentario y algunos de sus problemas más relevantes", en En torno a la democracia en España: temas abiertos del sistema politico español, Juan Luis Paniagua Soto, Juan Carlos Monedero (eds.), Tecnos, Madrid, 1999, págs. 449-471.

- "Responsabilidad y control: rendición de cuentas del Gobierno", en Representación y calidad de la democracia en España, Antonia Martínez (ed.), Tecnos, Madrid, 2006, págs. 165-178.

GUTIÉRREZ GUTIÉRREZ, Ignacio: Los controles de la legislación delegada, Centro de Estudios Constitucionales, Madrid, 1995.

- "Sobre el control parlamentario de los Decretos legislativos", en Problemas actuales del control parlamentario: VIJornadas de Derecho Parlamentario, Congreso de los Diputados, Madrid, 1997, págs. 855-874.

HAKANSSON NIETO, Carlos: "Una aproximación a los instrumentos de control parlamentario en la Constitución Española de 1978", Díkaion: revista de actualidad jurídica, n. ${ }^{\circ}$ 12, 2003.

HERNANDO GARCÍA, Pedro J.: «El proceso de reforma institucional de la Constitución italiana: las conclusiones de la commissione bicamerale y el control parlamentario", en Parlamento y control del Gobierno: V Jornadas de la Asociación Española de Letrados de Parlamentos, Francesc Pau i Vall (coord.), Aranzadi, Pamplona, 1998, págs. 127-174.

HOLGADO GONZÁLEZ, María: "De Santer a Barroso: experiencias de control parlamentario sobre la Comisión Europea", Revista de estudios Politicos, n. ${ }^{\circ}$ 129, 2005.

JIMÉNEZ CAMPO, Javier: "Sobre el control parlamentario en Comisión", en Política y Sociedad: estudios en homenaje a Francisco Murillo Ferrol, Centro de Estudios Constitucionales, Madrid, 1987, vol. 1, págs. 477-492.

KUNIG, Philip: "Control parlamentario del Ejecutivo. Alemania" en Democracia representativa y parlamentarismo: Alemania, España, Gran Bretaña e Italia. IX Jornadas de Derecho Constitucional Comparado, Antonio López Pina (dir.), Senado, Madrid, 1994, págs. 257-266.

LAVILLA RUBIRA, Juan José: “Congreso de los Diputados y demás poderes públicos: información, control y responsabilidad" en Estudios sobre la Cons- 
titución Española: homenaje al Profesor Eduardo García de Enterría, Civitas, Madrid, 1991, vol. III, págs. 2003-2056.

- "Control parlamentario del Ejecutivo" en Democracia representativa y parlamentarismo: Alemania, España, Gran Bretaña e Italia. IX Jornadas de Derecho Constitucional Comparado, Antonio López Pina (dir.), Senado, Madrid, 1994, págs. 267-276.

LÓPEZ AGUILAR, Juan Fernando: "Control parlamentario: centralidad y funcionalidad del Parlamento", Revista de Ciencias Jurídicas, n. 2, 1997, págs. $195-222$.

- "Una reflexión a propósito del control parlamentario del ejercicio del derecho de gracia", Revista de las Cortes Generales, n. ${ }^{\circ}$ 37, 1996.

LÓPEZ GUERRA, Luis: "La función de control de los Parlamentos, problemas actuales", en El Parlamento y sus transformaciones actuales: jornadas organizadas por la Asamblea Regional de Murcia, Ángel Garrorena Morales (ed.), Tecnos, Madrid, 1990, págs. 233-246.

- "El Control parlamentario como instrumento de las minorías", Anuario de Derecho Constitucional y Parlamentario, n. ${ }^{\circ}$ 8, 1996.

- "El titular del control parlamentario", en Problemas actuales del control parlamentario: VI Jornadas de Derecho Parlamentario, Congreso de los Diputados, Madrid, 1997, págs. 155-178.

LÓPEZ DE LERMA i LÓPEZ, Joseph: "Agencias independientes: origen, naturaleza jurídico-constitucional y control parlamentario", Revista de las Cortes Generales, n. ${ }^{\circ}$ 56, 2002, págs. 7-44.

LUCAS VERDÚ, Pablo: "El control por el Senado de la política gubernamental: (¿responsabilidad política del Gobierno ante el Senado?)", en El control parlamentario en las democracias pluralistas: (el proceso constitucional español), Labor, Barcelona, 1978, págs. 361-371

LUSTGARTEN, Laurence: "Control parlamentario del Ejecutivo. Gran Bretaña" en Democracia representativa y parlamentarismo: Alemania, España, Gran Bretaña e Italia. IX Jornadas de Derecho Constitucional Comparado, Antonio López Pina (dir.), Senado, Madrid, 1994, págs. 219-231.

MARCISIDOR ARTARAZ, Eduardo: "El control del Gobierno y de la Administración por la institución parlamentaria", en II Jornadas de Estudio sobre el Estatuto de Autonomía del País Vasco, Oñate, San Sebastián, 1991, págs. 1119-1191.

MARCUELLO BENEDICTO, Juan Ignacio: La práctica parlamentaria en el reinado de Isabel II, Congreso de los Diputados, Madrid, 1986.

MARTÍN-RETORTILLO BAQUER, Lorenzo: "De la separación y control de los poderes en el sistema constitucional español", Revista del Centro de Estudios Constitucionales, n. ${ }^{\circ} 4,1989$.

MARTÍNEZ LÓPEZ-MUÑIZ, José Luis: «La Administración Pública para el control parlamentario", Hacienda pública española, n. ${ }^{\circ}$ 80, 1983.

MARTÍNEZ-ELIPE, León: "Artículo 108: la responsabilidad política", (revisado y actualizado por José Antonio Moreno Ara), en Comentarios a la Constitución Española de 1978, Óscar Alzaga Villaamil (dir.), Cortes Generales, Madrid, 1996-1999, vol. VII, págs. 631-667. 
- Fiscalización política del Gobierno, Aranzadi, Elcano (Navarra), 2000-2002.

MARTÍNEZ TOMÁS, Antonio: "Los diputados o senadores interventores generales?: una página de Historia parlamentaria", en Control del sector público, Instituto de Estudios Fiscales, Madrid, 1981, págs. 793-808.

MELLADO PRADO, Pilar: La responsabilidad politica del Gobierno en el ordenamiento español, Congreso de los Diputados, Madrid, 1988.

MENÉNDEZ ALZAMORA, Manuel: "El Parlamento y las autoridades independientes de control", Corts. Anuario de Derecho Parlamentario, n. ${ }^{\circ}$ 14, 2003.

MERTEHIKIAN, Eduardo: "Algunas consideraciones jurídicas acerca del control parlamentario del sector público nacional", en Derecho Administrativo: obra colectiva en homenaje al Profesor Miguel S. Marienhoff, Juan Carlos Cassagne (coord.), 1998, págs. 419-430.

MOLAS, Isidre y PITARCH, Ismael: «Las Cortes Generales en el sistema parlamentario de Gobierno", en Temas Clave de la Constitución Española, Tecnos, Madrid, 1987.

MONTEJO VELILLA, Salvador: "El control de la política del Ejecutivo en materia financiera" en Los parlamentos de Europa y el Parlamento Europeo, José María Gil-Robles y Gil-Delgado (dir.), Enrique Arnaldo Alcubilla (coord.), Cyan, Madrid, 1997, págs. 231-237.

MONTERO GIBERT, José Ramón y GARCÍA MORILLO, Joaquín: El control parlamentario, Tecnos, Madrid, 1984.

MORA-DONNATO, Cecilia: "Instrumentos constitucionales para el control parlamentario", Cuestiones constitucionales: Revista mexicana de Derecho Constitucional, n. ${ }^{\circ}$ 4, 2001.

MURILLO FERROL, Francisco: "El marco socio-político del control parlamentario", en El control parlamentario del Gobierno en las democracias pluralistas: III Jornadas Internacionales de Ciencia Politica y Derecho Constitucional, Labor, Barcelona, 1978, págs: 44-55.

NOGUEIRA ALCALÁ, Humberto: "El control parlamentario en Chile», Contribuciones, n. ${ }^{\circ}$ 4, 1997.

ORTEGA SANTIAGO, Carlos Gonzalo: «Los parlamentarios y los grupos como sujetos del control parlamentario en el procedimiento legislativo", Problemas actuales del control parlamentario: VI Jornadas de Derecho Parlamentario, Congreso de los Diputados, Madrid, 1997, págs. 739-770.

ORTÍ BORDÁS, José Miguel: "Consideraciones sobre el control parlamentario" en Manuel Fraga: homenaje académico, Fundación Cánovas del Castillo, Madrid, 1997, vol. 2, págs. 1207-1241.

OSÉS ABANDO, Jesús María y FIGUEROA LARANDOGOITIA, Alberto: "La evaluación legislativa como control parlamentario", en Parlamento y control del Gobierno: VJornadas de la Asociación Española de Letrados de Parlamentos, Francesc Pau i Vall (coord.), Aranzadi, Pamplona, 1998, págs. 213-240.

- "El control del poder público en la Constitución Española" en La Constitución Argentina de nuestro tiempo, Roberto Dromi y Jorge Sáenz (coords.), Ciudad Argentina, Buenos Aires, 1996, págs. 213-228. 
PASCUA MATEO, Fabio: "En los intersticios del reglamento: análisis de las facultades de dirección política de las Cámaras parlamentarias", Revista de las Cortes Generales, n. ${ }^{\circ}$ 54, 2001.

PAU i VALL, Francesc: "La función parlamentaria de control", en Las funciones de los Parlamentos en Italia y en España, Asociación Española de Letrados de Parlamentos, Barcelona, y Aranzadi, Elcano (Navarra), 2001, págs. 129145.

PEDROZA DE LA LLAVE, Susana Talía: "Breve análisis de los actos de control parlamentario: estudio comparativo con relación a los países iberoamericanos" en Estudios de Teoría del Estado y Derecho Constitucional en bonor de Pablo Lucas Verdú, Raul Morodo y Pedro de Vega (dirs.), Universidad Complutense de Madrid, Madrid, e Instituto de Investigaciones Jurídicas de la Facultad de Derecho, México, 2001, vol. 3, págs. 2241-2263.

PIERRE, Eugène: Traité de droit politique électoral et parlementaire, París, Loysel, 1989.

PINO CARAZO, Ana del: "El control parlamentario de la Administración institucional en la Comunidad de Madrid", Asamblea:revista parlamentaria de la Asamblea de Madrid, n. ${ }^{\circ}$ 1, 2004, pág. 421.

PIÑAR MAÑAS, José Luis: "El control parlamentario de la Administración institucional", en Problemas actuales del control parlamentario: VIJornadas de Derecho Parlamentario, Congreso de los Diputados, Madrid, 1997, págs. 489-499.

PORTERO MOLINA, José Antonio: El control parlamentario del Gobierno, Institut de Ciènces Polítiques i Socials, Barcelona, 1998.

— "Cortes Generales y Gobierno: configuración y relaciones 1978-2000", en Aspects de la pratique constitutionnelle en France et en Espagne de 1958 et 1978 à 1999. Textes réunis et présentés par Dmitri Lavroff, Maison des pays ibériques, Bordeaux, 2001, págs. 223-252.

PRESNO LINERA, Miguel Ángel: Sistema de partidos y control parlamentario", Revista de las Cortes Generales, n. ${ }^{\circ} 46,1999$.

RASTROLLO ROJAS, José Manuel: «El Parlamento y los medios de comunicación: una aproximación a la cuestión de la eficacia del control parlamentario", en Problemas actuales del control parlamentario: VIJornadas de Derecho Parlamentario, Congreso de los Diputados, Madrid, 1997, págs. 875-892.

REBOREDO I CIVERA, Rosa: «Más allá del control parlamentario, el impulso político", en Parlamento y control del Gobierno: VJornadas de la Asociación Española de Letrados de Parlamentos, Francesc Pau i Vall (coord.), Aranzadi, Pamplona, 1998, págs. 303-330.

RECODER DE CASO, Emilio: "El control parlamentario del gasto público", en Problemas actuales del control parlamentario: VI Jornadas de Derecho Parlamentario, Congreso de los Diputados, Madrid, 1997, págs. 477-488.

- "El control parlamentario del presupuesto", en Parlamento y control del Gobierno: VJornadas de la Asociación Española de Letrados de Parlamentos, Francesc Pau i Vall (coord.), Aranzadi, Pamplona, 1998, págs. 331-344. 
RENNELLA, María Paula: "El control parlamentario en el ordenamiento jurídico argentino", Documentación Administrativa, n. ${ }^{\circ}$ 269-270, 2004.

REQUEJO PAGÉS, Juan Luis: "Las relaciones entre el Gobierno y las Cortes Generales", Revista Española de Derecho Constitucional, n. ${ }^{\circ}$ 70, 2004.

REVENGA SÁNCHEZ, Miguel: "Las tribulaciones del "Llanero solitario". El control parlamentario de las acciones encubiertas por el Congreso norteamericano", Revista de Estudios Políticos, n. ${ }^{\circ}$ 94, 1996.

RIPOLLÉS SERRANO, María Rosa: "Las Cortes Generales: tradición y modernidad, de las funciones tradicionales a la legitimación del sistema político" en Escritos en conmemoración del XXV aniversario de la Constitución, María Isabel Álvarez Vélez (coord.), Universidad Pontificia de Comillas, Madrid, 2004, págs. 55-78.

RODRÍGUEZ BEREIJO, Álvaro: "El control parlamentario de la política económica", Hacienda Pública Española, n. ${ }^{\circ}$ 97, 1985.

RODRIGUEZ-ZAPATA PÉREZ, Jorge: "El poder judicial como límite de la potestad de control de las Cortes Generales", Revista Española de Derecho Constitucional, n. ${ }^{\circ}$ 9, 1983.

RUBIO LLORENTE, Francisco: "El control parlamentario", Revista Parlamentaria de Habla Hispana, n. ${ }^{\circ}$ 1, 1985.

SÁENZ COSCULLUELA, Javier: "Democracia y parlamento", Temas para el debate, n. ${ }^{\circ} 13,1995$.

SAGÜÉS, NÉSTOR, Pedro: "Formas de gobierno: aproximaciones a una teoría del control parlamentario sobre el Poder Ejecutivo", Lecturas Constitucionales Andinas, n. ${ }^{\circ}$ 2, 1993.

SÁINZ ARNAIZ, Alejandro: "Sobre la efectividad del derecho de los parlamentarios vascos a recabar información del Gobierno autónomo: comentario a la STC de 9 de junio de 1987", La ley, n. ${ }^{\circ} 1,1988$.

SÁINZ MORENO, Fernando: "Control parlamentario sobre el ejercicio de la función jurisdiccional", Problemas actuales del control parlamentario: VI Jornadas de Derecho Parlamentario, Congreso de los Diputados, Madrid, 1997, págs. 53-64.

SALA ARQUER, José Manuel: "El control de la actividad normativa del Ejecutivo" en Los Parlamentos de Europa y el Parlamento Europeo, José María Gil-Robles y Gil-Delgado (dir.), Enrique Arnaldo Alcubilla (coord.), Cyan, Madrid, 1997, págs. 223-230.

SALINAS DE FRÍAS, Ana: "La reafirmación del necesario control parlamentario de la actividad convencional del Ejecutivo. Comentario a la Sentencia 155/2005, de 9 de junio, del Tribunal Constitucional", Revista Española de Derecho Internacional, vol. 57, n. ${ }^{\circ}$ 1, 2005.

SALVADOR MARTÍNEZ, María: "Sobre el control parlamentario de la televisión" en Ciudadanos e instituciones en el constitucionalismo actual, José Asensi Sabater (coord.), Tirant lo Blanch, Madrid, 1997, págs. 539-555.

SÁNCHEZ NAVARRO, Ángel J.: "Control parlamentario y minorías", Revista de Estudios Políticos, n. ${ }^{\circ}$ 88, 1995.

- La oposición parlamentaria, Congreso de los Diputados, Madrid, 1997. 
SÁNCHEZ DE DIOS, Manuel: "La esencia del régimen: el control parlamentario del Gobierno", Política y Sociedad, n. ' 20, 1995.

- "La práctica del control parlamentario en el Congreso de los Diputados entre 1997 y 2000", Revista de las Cortes Generales, n. ${ }^{\circ}$ 57, 2002.

— "Output of the Spanish Cortes (1979-2000): A case of adaptation to party Government", European Journal of Political Research, vol. 45, n. ${ }^{\circ}$ 4, 2006.

SÁNCHEZ MORÓN, Miguel: "El Defensor del Pueblo como medio de control parlamentario de la Administración", en El fortalecimiento del Ombudsman iberoamericano, Universidad de Alcalá de Henares, Alcalá de Henares, 1999, págs. 185-194.

SANTAMARÍA PASTOR, Juan Alfonso: "La actividad del Gobierno y de la Administración pública como objeto del control parlamentario", en Problemas actuales del control parlamentario: VIJornadas de Derecho Parlamentario, Congreso de los Diputados, Madrid, 1997, págs. 455-476.

SANTAOLALLA LÓPEZ, Fernando: "La función de control y la Ciencia del Derecho Constitucional", Revista de las Cortes Generales, n. ${ }^{\circ}$ 12, 1987.

- Derecho parlamentario español, Espasa Calpe, Madrid, 1990.

SANTOS CANALEJO, Eugenio de: "Bicameralismo y control parlamentario", en Problemas actuales del control parlamentario: VIJornadas de Derecho Parlamentario, Congreso de los Diputados, Madrid, 1997, págs. 179196.

SEVILLA ANDRÉS, Diego: "Orígenes del control parlamentario en España (18101874)" en El control parlamentario del Gobierno en las democracias pluralistas: III Jornadas Internacionales de Ciencia Politica y Derecho Constitucional, Labor, Barcelona, 1978, págs. 123-148.

SIMÓN ACOSTA, Eugenio: «El control parlamentario de las actividades de las empresas públicas privatizadas", Actualidad jurídica Aranzadi, n. ${ }^{\circ}$ 552, 2002, pág. 3.

SOLÉ TURA, Jordi: «El control parlamentario en el período constituyente y en la Constitución de 1978", Parlamento y sociedad civil, M.A. Aparicio (coord.), Cátedra de Derecho Político, Universidad de Barcelona, Barcelona, 1980, págs. 31-47.

SOLÍS FALLAS, Alex: El control parlamentario, Asamblea Legislativa, Costa Rica, 1995.

SOLOZÁBAL ECHAVARRÍA, Juan José: «El régimen parlamentario y sus enemigos: reflexiones sobre el caso español", Revista de estudios políticos. Nueva época, n. ${ }^{\circ}$ 93, 1996.

SUBIRATS, Joan: El control parlamentario de la empresa pública: análisis de su problemática en Francia, Italia y España, Tesis-Universidad de Barcelona, Barcelona, 1980.

TENORIO MACÍAS, Pedro: "El control parlamentario de la seguridad social", en Control del sector público, Instituto de Estudios Fiscales, Madrid, 1981, págs. 113-196.

TOMÁS VILLARROYA, Joaquín: "Orígenes del control parlamentario en España”, Revista de Estudios Políticos, n. ${ }^{\circ}$ 132, 1963. 
TUR AUXINA, Rosario: El control parlamentario de los Decretos-leyes, Centro de Estudios Políticos y Constitucionales, Madrid, 2002.

VANOSSI, Jorge Reinaldo: "Democracia constitucional: pluralismo y control", en El control parlamentario del Gobierno en las democracias pluralistas: III Jornadas Internacionales de Ciencia Politica y Derecho Constitucional, Labor, Barcelona, 1978, págs. 17-45.

VARELA SUANZES, Joaquín: "El control parlamentario del Gobierno en la Historia constitucional española", en El Parlamento a debate, Trotta, Madrid, 1997, págs. 59-71.

- "El control parlamentario del Gobierno en la historia constitucional española" en El Parlamento en el tiempo, Parlamento Vasco, Vitoria-Gasteiz, 2003, págs. 17-33.

VICIANO PASTOR, Roberto: "A vueltas con el concepto de control parlamentario", Cuadernos Constitucionales de la Cátedra Fadrique Furió Ceriol, n. ${ }^{\circ}$ 30-31, 2000.

VILLACORTA MANCEBO, Luis: Centralidad parlamentaria, delegación legislativa y posibilidades de control, Dykinson, Madrid, 1999.

VINTRÓ I CASTELLS, Joan: "Los procedimientos no legislativos", en Parlamentos y Derecho, Parlamento Vasco, Vitoria-Gasteiz, 1991, págs. 365-378.

VITORINO, Antonio: "El control parlamentario del Gobierno", Revista de Estudios Políticos, n. ${ }^{\circ}$ 60-61, 1988.

\section{OTORGAMIENTO Y RETIRADA DE LA CONFIANZA PARLAMENTARIA: INVESTIDURA, CUESTIÓN DE CONFIANZA, MOCIÓN DE CENSURA.}

AJA, Eliseo: "El nombramiento, control e impulso político del Gobierno", en El sistema jurídico de las Comunidades Autónomas, Tecnos, Madrid, 1985, págs. 251-267.

BAR CENDÓN, Antonio: El Presidente del Gobierno en España: encuadre constitucional y práctica política, Civitas, Madrid, 1983.

BUSTOS GISBERT, Rafael: La responsabilidad politica del Gobierno: ¿realidad o ficción?: la necesaria reformulación de un principio esencial del sistema parlamentario, Colex, Madrid, 2001.

CARBALLO ARMAS, Pedro y ZABALLOS GONZÁLEZ, Clemente: “Consideraciones en torno al control parlamentario: la moción de censura", Revista de ciencias jurídicas, n. ${ }^{\circ}$ 1, 1996, págs. 301-318.

FERNÁNDEZ SEGADO, Francisco: "La cuestión de confianza: artículo 112." ", en Comentarios a la Constitución española de 1978, Óscar Alzaga Villaamil (dir.), Cortes Generales, Madrid, 1996-1999, T. VIII, págs. 823-869.

- "La moción de censura: artículo 113.․", en Comentarios a la Constitución española de 1978, Óscar Alzaga Villaamil (dir.), Cortes Generales, Madrid, 1996-1999, págs. 15-107. 
- "La remoción del Gobierno: artículo 114. " ", en Comentarios a la Constitución española de 1978, Óscar Alzaga Villaamil (dir.), Cortes Generales, Madrid, 1996-1999, págs. 190-149.

GONZÁLEZ-TREVIJANO, Pedro J.: La cuestión de confianza, McGraw-Hill, Madrid, 1996.

GONZALO, Manuel: "Crónica parlamentaria: moción de censura socialista al Gobierno", Revista de Derecho Político, n. ${ }^{\circ}$ 7, 1980.

SÁNCHEZ DE DIOS, Fernando: La moción de censura: (un estudio comparado), Congreso de los Diputados, Madrid, 1992.

SANTAOLALLA LÓPEZ, Fernando: "Artículo 112", en Comentarios a la Constitución, Civitas, Madrid, 2001, págs. 1720-1729.

- "Artículo 113", en Comentarios a la Constitución, Civitas, Madrid, 2001, págs. 1730-1744.

VÍRGALA FORURIA, Eduardo: La moción de censura en la Constitución de 1978 (y en la historia del parlamentarismo español), Centro de Estudios Constitucionales, Madrid, 1988.

\section{INSTRUMENTOS DE CONTROL PARLAMENTARIO (I):}

\section{LAS PREGUNTAS Y LAS INTERPELACIONES PARLAMENTARIAS}

BASTIDA FREIJEDO, F. «Investidura de los presidentes autonómicos y parlamentarismo negativo", bttp://constitución. rediris.es/oapa/gobierno.btm, 2005.

CASTELLÓ BORONAT, Fernando: "El control parlamentario: las preguntas al Presidente del Gobierno", Corts. Anuario de Derecho Parlamentario, n. ${ }^{\circ} 4$ extra, 1997.

FERNÁNDEZ DE SIMÓN BERMEJO, Encarna: "Algunas cuestiones sobre la singularidad de las interpelaciones en el Reglamento de la Asamblea Regional de Murcia", Corts. Anuario de Derecho Parlamentario, n. ${ }^{\circ}$ 7, 1999.

LUCAS VERDÚ, Pablo: "Interpelación", en Nueva enciclopedia jurídica, Francisco Seix (ed.), Barcelona, 1968, vol. XIII, págs. 255-257.

MALUENDA VERDÚ, Rafael: "Control del Gobierno: la interpelación" Corts. Anuario de Derecho Parlamentario, n. ${ }^{\circ} 4$ extra, 1997.

MARCO MARCO, Joaquín J. "Las preguntas parlamentarias: las preguntas del interés general al Presidente del Ejecutivo", en Parlamento y control del Gobierno: VJornadas de la Asociación Española de Letrados de Parlamentos, Francesc Pau i Vall (coord.), Aranzadi, Pamplona, 1998, págs. 283-290.

MARTÍN-RETORTILLO BAQUER, Lorenzo: "El "amplio margen de libertad" en el uso de los privilegios parlamentarios y su incidencia sobre los derechos fundamentales: Auto del Tribunal Constitucional 147/1982, de 22 de abril, sobre el alcance de las preguntas parlamentarias", Revista Española de Derecho Constitucional, n. ${ }^{\circ} 11,1984$, págs. 121-138.

MARTÍNEZ SOSPEDRA, M.: El régimen parlamentario y el sistema de partidos (nota sobre el anteproyecto constitucional)", en El control parlamentario 
del Gobierno en las democracias pluralistas (el proceso constitucional español): III Jornadas Internacionales de Ciencia Policia y Derecho Constitucional, Labor, Barcelona, 1978, págs. 205-214.

MOLAS, Isidre: "El derecho de interrogación", en El Gobierno en la Constitución española y en los Estatutos de Autonomía, Diputació de Barcelona, Barcelona, 1985, págs. 245-264.

MOLERO ALONSO, Diego: Las interpelaciones parlamentarias, Congreso de los Diputados, Madrid, 2003.

OSÉS ABANDO, José: «Interpelaciones y preguntas: sugerencias para su reforma", Corts. Anuario de Derecho Parlamentario, n. ${ }^{\circ}$ 5, 1998.

PULIDO QUECEDO, Manuel: "Las preguntas parlamentarias ante el Tribunal Constitucional", Repertorio Aranzadi del Tribunal Constitucional, n. ${ }^{\circ}$ 1, 2001, págs. 1856-1863.

RIDAURA MARTÍNEZ, María Josefa: “Las preguntas parlamentarias en los parlamentos autonómicos", Revista de la Facultad de Derecho de la Universidad Complutense, n. ${ }^{\circ} 15,1989$.

RODRIGUEZ IBÁNEZ, José Enrique y GONZÁLEZ TEMPRANO, Antonio: “Interpelación" en Diccionario de ciencias sociales, Instituto de Estudios Políticos, Madrid, 1975, págs. 1157-1159.

SANTAOLALLA LÓPEZ, Fernando: “Las preguntas, instrumento parlamentario de control", Documentación Administrativa, n. ${ }^{\circ}$ 178, 1978.

- El Parlamento y sus instrumentos de información (preguntas, interpelaciones y comisiones de investigación), Edersa, Madrid, 1982.

4. INSTRUMENTOS DE CONTROL PARLAMENTARIO (II): LAS COMISIONES DE INVESTIGACIÓN PARLAMENTARIA

AGUILLÓ LÚCIA, Lluis: «El debate secreto en las comisiones de investigación y el derecho al honor, la intimidad y la propia imagen", en Parlamento y opinión pública, Francesc Pau i Vall (coord.), Tecnos, Madrid, 1995, págs. 203-209.

AMORÓS DORDA, Francisco Javier: "Comisiones de investigación: artículo 76. ${ }^{\circ}$, en Comentarios a las leyes políticas. Constitución española de 1978, Oscar Alzaga Villaamil (dir.), Edersa, Madrid, 1983-1989, t. VI, págs. 559-593. ARÉVALO GUTIÉRREZ, Alfonso: «Reflexiones sobre las comisiones de investigación o encuestas parlamentarias en el ordenamiento constitucional español", Revista de las Cortes Generales, n. ${ }^{\circ} 11,1987$.

- "Comisiones de investigación y de encuesta, en Las comisiones parlamentarias, Parlamento Vasco, Vitoria-Gasteiz, 1994, págs. 361-433.

ASTARLOA HUARTE-MENDICOA, Ignacio y CAVERO GÓMEZ, Manuel: Comisiones de investigación: artículo 76", en Comentarios a la Constitución española de 1978, Óscar Alzaga Villaamil (dir.), Cortes Generales, Madrid, 1996-1999, T. VI, págs. 569-663. 
- "Cuestiones resueltas y cuestiones pendientes en el régimen jurídico de las comisiones de investigación", Teoría y realidad constitucional, n. ${ }^{\circ}$ 1, 1998, págs. 123-181.

CAAMAÑO DOMÍNGUEZ, Francisco: “Comisiones parlamentarias de investigación $v s$. poder judicial: paralelismo o convergencia: (apuntes para su debate)", Anuario de Derecho Constitucional y Parlamentario, n. ${ }^{\circ} 6$, 1994.

CIRIELO SOLETO, Francisco Javier: "La no comparecencia y el falso testimonio ante las comisiones de investigación: análisis del art. 502 del Código Penal", Corts. Anuario de Derecho Parlamentario, n. ${ }^{\circ}$ 13, 2002.

FERNÁNDEZ-VIAGAS BARTOLOMÉ, Plácido: "La comparecencia de los ciudadanos ante las comisiones de investigación de las Asambleas Legislativas", Revista de las Cortes Generales, n. ${ }^{\circ}$ 27, 1992.

GARCÍA MAHAMUT, Rosario: Las comisiones parlamentarias de investigación en el Derecho Constitucional español, McGraw-Hill, Madrid, 1996.

- "El reconocimiento del derecho de la minoría a crear Comisiones de investigación resultaría suficiente para un ejercicio eficaz del control parlamentario?", Cuadernos de Derecho Público, n. ${ }^{\circ}$ 17, 2002.

GARCÍA MORILLO, Joaquín: "Principio de autonomía y control parlamentario: el supuesto de las Comisiones de investigación", Revista Vasca de Administración Pública, n. ${ }^{\circ} 44,1996$.

- "El control parlamentario de las Cortes Generales y las Asambleas Legislativas de las Comunidades Autónomas: autonomía y comisiones de investigación", en Problemas actuales del control parlamentario: VIJornadas de Derecho Parlamentario, Congreso de los Diputados, Madrid, 1997, págs. 101-120.

GRECIET GARCÍA, Esteban: "Posición constitucional de las Comisiones de investigación y protección de los derechos de los comparecientes", Asamblea: revista Parlamentaria de la Asamblea de Madrid, n. ${ }^{\circ}$ 10, 2004.

GUDE FERNÁNDEZ, Ana: Las comisiones parlamentarias de investigación, Universidad de Santiago de Compostela, Intercambio Científico, Santiago de Compostela, 2000.

JIMÉNEZ DÍAZ, Andrés: "Comisiones de investigación, intimidad e información tributaria", Revista Española de Derecho Constitucional, n. ${ }^{\circ}$ 60, 2000.

LUCAS MURILLO DE LA CUEVA, Pablo: "Le comisión d'inchiesta nell'ordinamento costituzionale spagnolo", en Le inchieste delle assemblee parlamentari, Giuseppe de Vergottini, Rimini: Maggioli, 1985, págs. 381-421.

- "Las Comisiones de investigación de las Cortes", en Revista de la Facultad de Derecho de la Universidad Complutense, n. ${ }^{\circ}$ 10, 1986.

MARTÍNEZ OCAMICA, Gutenberg: Fiscalización parlamentaria y comisiones investigadoras: análisis y propuestas, Santiago de Chile, Editorial Jurídica de Chile, 1998.

MASSÓ GARROTE, Marcos Francisco: Poderes y limites de la investigación parlamentaria en el Derecho Constitucional español, Congreso de los Diputados, Madrid, 2001. 
MEDINA RUBIO, Ricardo: La función constitucional de las comisiones parlamentarias de investigación, Civitas, Madrid, 1994.

MORA DONATO, Cecilia Judith: Las comisiones parlamentarias de investigación como órganos de control politico. Tesis doctoral que presenta Cecilia Judith Mora Donato; realizada bajo la dirección del Dr. D. Manuel Aragón Reyes, Universidad Autónoma de Madrid, Madrid, 1997.

MORENO CARDOSO, Alfonso: "La investigación parlamentaria en España", $A c$ tualidad administrativa, n. ${ }^{\circ}$ 7, 1989.

NAVAS CASTILLO, Florentina: La función legislativa y de control en comisión parlamentaria: comisiones de investigación y comisiones legislativas permanentes con competencia legislativa plena, Colex, Madrid, 2000.

- "Las comisiones de investigación y el Poder Judicial", Revista del Poder Judicial, 3. ${ }^{\mathrm{a}}$ época, n. ${ }^{\circ}$ 60, 2000.

OTAOLA, Javier: "Catarsis y parlamentarismo: las comisiones de investigación", Claves de razón práctica, n. ${ }^{\circ}$ 29, 1993.

PÉREZ-UGENA Y COROMINA, Álvaro: “Comisiones de Investigación y Poder Judicial: la intromisión parlamentaria", Revista de la Facultad de Derecho de la Universidad Complutense, n. ${ }^{\circ}$ 86, 1994-1995.

RECODER DE CASSO, Emilio y GARCÍA-ESCUDERO MÁRQUEZ, Piedad: "Artículo 76" en Comentarios a la Constitución, Madrid, Civitas, 2001, págs. 1287-1301.

SANTAOLALLA LÓPEZ, Fernando: l Parlamento y sus instrumentos de información (preguntas, interpelaciones y comisiones de investigación), Edersa, Madrid, 1982.

TORRES BONET, María: Las comisiones de investigación; instrumentos de control parlamentario del gobierno, Congreso de los Diputados, Madrid, 1998.

TORRES MURO, Ignacio: Las comisiones parlamentarias de investigación, Madrid, Centro de Estudios Políticos y Constitucionales, 1998.

ZUÑIGA URBINA, Francisco: Control parlamentario y comisiones investigadoras (Parlamento ante la Reforma Constitucional)", Revista de Derecho Político, n. ${ }^{\circ} 45,1999$.

\section{INSTRUMENTOS DE CONTROL PARLAMENTARIO (III): COMPARECENCIAS ANTE LAS CÁMARAS Y SOLICITUDES DE INFORMACIÓN Y DOCUMENTACIÓN}

ARAGÓN REYES, Manuel: "Información parlamentaria y función de control" en Instrumentos de información de las cámaras parlamentarias: debate celebrado en el Centro de estudios Constitucionales, en colaboración con el Congreso de los Diputados y el Senado, Centro de Estudios Constitucionales, Madrid, 1994, págs. 13-35.

ARRUEGO RODRÍGUEZ, Gonzalo: "Sobre el derecho a la documentación de los parlamentarios en la jurisprudencia constitucional", Revista española de derecho constitucional, A. 23, n. ${ }^{\circ}$ 68, págs. 355-378. 
- "Ius in officium" parlamentario y respuesta a las solicitudes de documentación", en Gobierno y Constitución: actas del II Congreso de la Asociación de Constitucionalistas de España, Pablo Lucas Murillo de la Cueva (coord.), Tirant lo Blanch, Valencia, 2005, págs. 273-290.

CANO BUESO, Juan: El derecho de acceso a la documentación de los diputados en el ordenamiento parlamentario español, Congreso de los Diputados, Madrid, 1996.

CASTELLÁ ANDREU, Josep María: El derecho de acceso a la información de los parlamentos con sus asesores: comentario a la STC 181/89, de 3 de noviembre: comunicación a presentar en el Congreso de la Asociación Española de Derecho Constitucional y Ciencia Política, Valladolid, 1991.

DA SILVA OCHOA, Juan Carlos: «El derecho de los parlamentarios a la documentación", Revista de las Cortes Generales, n. ${ }^{\circ}$ 19,1990.

DÍEZ-PICAZO GIMÉNEZ, Luis María: "Actos de los procedimientos de control, impulso e información", Los actos del parlamento, Parlamento Vasco, Vitoria-Gasteiz, 1999, págs: 137-167.

GÁLVEZ MONTES, Javier: "Auxilio a las Cortes Generales: artículo 109.", en Comentarios a la Constitución española de 1978, dirigidos por Óscar Alzaga Villaamil, Cortes Generales, Madrid, 1996-1999, T. VIII, págs. 599-709.

GIL-ROBLES Y GIL DELGADO, José María: "Las comparecencias ante las comisiones de las Cortes: ¿control o información?, en Actualidad y perspectivas del derecho público a fines de siglo xx: homenaje al profesor Garrido Falla, Editorial Complutense, Madrid, 1992, Vol II, págs. 1949-1968.

JORQUERA MÍNGUEZ, Ginés: «El derecho de los diputados regionales a obtener de las autoridades públicas de información necesaria para el cumplimiento de sus funciones.", en III Jornadas de Parlamentos Autónomos, Corts Valencianas, Valencia, 1986, págs. 167-174.

LAVILLA RUBIRA, Juan José: “Congreso de los Diputados y demás poderes públicos, información, control y responsabilidad", en Estudios sobre la Constitución española: bomenaje al Profesor Eduardo García de Enterría, Sebastián Martín-Retortillo (coord.), Cívitas, Madrid, 1991.

MARCISIDOR ARTARAZ, Eduardo: "El derecho de los parlamentarios a recabar información", Revista vasca de administración pública, n. . 24, 1989.

- «El derecho de información de los parlamentarios en la jurisprudencia constitucional", Parlamento y justicia constitucional: IV Jornadas de la Asociación Española de Letrados de Parlamentos, Francesc Pau i Vall (coord.), Aranzadi, Pamplona, 1997, págs. 323-364.

MARIEZCURRENA, Martín Ignacio: "El derecho de los Diputados a solicitar informes", Asamblea: revista parlamentaria de la Asamblea de Madrid, n. ${ }^{\circ}$ 11, págs. 139-146.

MARTÍNEZ ELIPE, León: La presencia ministerial en las Cámaras: artículo 110. " (revisado y actualizado por José Antonio Moreno Ara), en Comentarios a la Constitución española de 1978, Óscar Alzaga Villamil (dir.), Cortes Generales, Madrid, 1996-1999- T. VIII, págs. 711-748. 
NAVAS CASTILLO, Antonia: "El Parlamento y el derecho a la información en su vertiente pasiva", en El derecho de la información, Pedro Tenorio Sánchez, Carmen Fernández Miranda (coords.), Universidad Nacional de Educación a Distancia, Madrid, 2001, págs. 279-321.

PEDROZA DE LA LLAVE, Susana Talía: “La comparecencia del Gobierno en el Parlamento español. Una forma de control parlamentario", Boletín Mexicano de Derecho Comparado, n. ${ }^{\circ} 86,1999$.

PEÑARANDA RAMOS, José Luis: Información parlamentaria, poderes públicos y sector público", en Instrumentos de información de las cámaras parlamentarias: debate celebrado en el Centro de Estudios Constitucionales, en colaboración con el Congreso de los Diputados y el Senado, Centro de Estudios Constitucionales, Madrid, 1994, págs. 37-80.

PÉREZ-SERRANO JÁUREGUI, Nicolás: "Derecho parlamentario e información", en Memoria del primer encuentro iberoamericano de bibliotecas parlamentarias, Cámara de Diputados, México, 1994.

SANTAOLALLA LÓPEZ, Fernando: "Artículo 109", en Comentarios a la Constitución, Madrid, Civitas, 2001, págs. 1675-1697.

SAINZ MORENO, Fernando: "Consideraciones sobre algunos límites del derecho de información de las Cámaras", en Instrumentos de información de las Cámaras parlamentarias: debate celebrado en el Centro de Estudios Constitucionales, en colaboración con el Congreso de los Diputados y el Senado, Centro de Estudios Constitucionales, Madrid, 1994, págs. 81 a 90.

SANZ PÉREZ, Ángel L.: "La función de control parlamentario en la Jurisprudencia del Tribunal Constitucional: Comentario a la STC 208/2003, de 1 de diciembre (RCL 2003,108)", Repertorio Aranzadi del Tribunal Constitucional, n. ${ }^{\circ}$ 1, 2004, págs. 2005-2028.

SORIANO HERNÁNDEZ, Enriqueta: "El derecho a la información de los diputados: el artículo 7 del Reglamento de las Cortes Valencianas", Revista de las Cortes Generales, n. ${ }^{\circ}$ 26, 1992.

TUDELA ARANDA, José: "La función parlamentaria de información política", en Parlamento y comunicación (nuevos retos): XI Jornadas de la Asociación Española de Letrados de Parlamentos, Francesc Pau i Vall (coord.), Asociación Española de Letrados de Parlamentos-Tecnos, Madrid, 2005, págs. 53-74.

XIFRA, Jordi: “La información como arma del Parlamento" en Las Cortes Generales, Instituto de Estudios Fiscales, Madrid, 1987, vol. III, págs. 2319-2334.

6. ESPECIALIDADES DEL CONTROL PARLAMENTARIO: EL CONTROL PARLAMENTARIO SOBRE MATERIAS CLASIFICADAS Y GASTOS RESERVADOS Y SOBRE LA POLÍTICA EXTERIOR Y LA POLÍTICA DE DEFENSA

ALONSO DE ANTONIO, Angel Luis: "El control parlamentario de la política exterior en la Constitución española de 1978", Revista de la Facultad de Derecho de la Universidad Complutense, n. ${ }^{\circ} 15,1989$. 
- Le contrôle parlamentaire des services de renseignement, Division des études de legislation comparèe du service des affaires européennes, Sénat, $\mathrm{Pa}$ rís, 2002.

ARCE GÓMEZ, Juan Carlos: “Control parlamentario en las instituciones europeas. El parlamentario europeo. Control presupuestario y control político", Problemas actuales del control parlamentario: VI Jornadas de Derecho Parlamentario, Congreso de los Diputados, Madrid, 1997, págs. 599-622.

AUBERT, Serge: Doit-on instaurer le contrôle parlamentaire sur les opérations extérieures, Riaux, Châteauneuf-val-de Bargis, 2004.

BENZO PEREA, Miguel: "El control parlamentario de la política exterior", en Los parlamentos de Europa y el Parlamento Europeo, José María Gil-Robles y Gil-Delgado (dir.), Enrique Arnaldo Acubilla (coord.), Cyan, Madrid, 1997, págs. 238-249.

CANO BUESO, Juan: "Información parlamentaria y secretos oficiales", Revista de las Cortes Generales, n. ${ }^{\circ}$ 42, 1997.

DELGADO-IRIBARREN GARCÍA-CAMPERO, Manuel: "El control parlamentario de la política gubernamental relativa a la Unión Europea", en Los parlamentos de Europa y el Parlamento Europeo, José María Gil-Robles y GilDelgado (dir.), Enrique Arnaldo Acubilla (coord.), Cyan, Madrid, 1997, págs. 250-267.

DORADO FRIAS, Fernando: "El control parlamentario de la política exterior", en Problemas actuales del control parlamentario: VI Jornadas de Derecho parlamentario, Congreso de los Diputados, Madrid, 1997, págs. 539-566.

FERNANDEZ NIETO, Josefa: "La desclasificación judicial del secreto de Estado. El control parlamentario y judicial. Reflexiones de una polémica", Publicación para el Mundo del Derecho, n. ${ }^{\circ}$ 112, 2000.

FERNÁNDEZ-MIRANDA ALONSO, Faustino: El control parlamentario de la política exterior en el derecho español, Instituto de Estudios Administrativos, Madrid, 1977.

GARCÍA-TREVIJANO GARNICA, Ernesto: "Materias clasificadas y control parlamentario", Revista Española de Derecho Constitucional, n. ${ }^{\circ}$ 48, 1996.

GUILLÉN LÓPEZ, Enrique: "Ciudadanos, parlamento y control de la política de defensa del Estado", en Los derechos humanos: libro homenaje al Excmo.. Sr. D. Luis Portero García, José Miguel Zugaldía Espinar y Eduardo Roca Roca (coords.), Universidad de Granada, Granada, 2001, págs. 435463.

KRETSCHMER, Gerald: "Control parlamentario y cooperación interparlamentaria en la incorporación, aplicación y seguimiento de las consecuencias de las normas del derecho europeo en los Estados miembros de la Unión Europea", Revista de las Cortes Generales, n. ${ }^{\circ} 33,1994$, págs. 147-182.

LÓPEZ GARRIDO, Diego: "Algunos datos sobre el control de la política de defensa y la administración militar en el Congreso de los Diputados", Revista de las Cortes Generales, n. ${ }^{\circ}$ 8, 1986.

MARTÍN MARTÍNEZ, Magdalena María: "El control parlamentario de la política comunitaria", Revista de instituciones europeas, vol. 22, n. ${ }^{\circ}$ 2, 1995. 
MATIA PORTILLA, Francisco Javier: "Hacia un control parlamentario más efectivo sobre la actuación europea del Gobierno francés", Revista de Derecho Comunitario Europeo, n. ${ }^{\circ}$ 6, 1999.

MOLINA DEL POZO, Carlos Francisco: El control parlamentario de las políticas comunitarias: legitimidad, eficacia y participación, Cálamo, Barcelona, 2004.

PÉREZ TREMPS, Pablo: "El control parlamentario de la política exterior" en $E l$ parlamento y sus transformaciones actuales: jornadas organizadas por la Asamblea Regional de Murcia, Ángel Garrorena Morales (ed.), Tecnos, Madrid, 1990.

QUINLAN, Michael: "El papel y el control de las fuerzas armadas en las sociedades democráticas", Revista de la OTAN, n. ${ }^{\circ}$, págs. 29-33.

REMIRO BROTÓNS, Antonio: Politica exterior de defensa y control parlamentario, Centro de Estudios Políticos y Constitucionales, Madrid, 1988.

REVENGA SÁNCHEZ, Miguel: “El persistente (des)control del Centro Nacional de Inteligencia", en La defensa del Estado: actas del I Congreso de la Asociación de Constitucionalistas de España, Luis López Guerra y Eduardo Espín Templado (coords.), Tirant lo Blanch, Valencia, 2004, págs. 209-221.

ROCA FERNÁNDEZ, Maria José: «El control parlamentario y constitucional del Poder Exterior. Estudio comparado del estado actual de la cuestión en el Derecho alemán y español", Revista Española de Derecho Constitucional, n. ${ }^{\circ} 56,1999$.

VEGA FERNÁNDEZ, Enrique: Control parlamentario del sector de la seguridad: principios, mecanismos y prácticas, Instituto Universitario «General Gutiérrez Mellado" de Investigación sobe la Paz, la Seguridad y la Defensa, Madrid, 2006.

VICIANO PASTOR, Roberto: “La Comisión Mixta para la Unión Europea: algo más que un mero instrumento de control parlamentario", Parlamento $y$ Constitución, n. ${ }^{\circ}$ 3, 1999.

VINOCOUR FORNIERI, Sergio: «El control parlamentario de la política exterior y de las negociaciones comerciales internacionales. Un instrumento esencial para reestablecer el equilibrio de poderes en Costa Rica ante los efectos de la globalización y la internacionalización del derecho interno", Revista Parlamentaria, vol. 10, n. ${ }^{\circ}$ 2, 2002.

\section{EL CONTROL PARLAMENTARIO EN LAS COMUNIDADES AUTÓNOMAS}

AGUILÓ LUCÍA, Lluis: "Los Estatutos de Autonomía y el control parlamentario", en III Jornadas Internacionales de Ciencia Política y Derecho Constitucional: el control parlamentario del Gobierno en las democracias pluralistas, Labor, Barcelona, 1978, págs. 316-326.

AJA, Eliseo: "El control parlamentario del Gobierno en las Comunidades Autónomas", en El Parlamento y sus transformaciones actuales: jornadas or- 
ganizadas por la Asamblea Regional de Murcia (11-13 de abril de 1988), Ángel Garrorena Morales (ed.), Tecnos, Madrid, 1990, págs. 300-301.

ARCE JANÁRIZ, Alberto: "La organización del control parlamentario en las Asambleas de las Comunidades Autónomas", Revista Jurídica de Asturias, n. ${ }^{\circ} 19,1995$.

- "Insuficiencias del control parlamentario en las Comunidades Autónomas", en Informe Comunidades Autónomas 1995, Instituto de Derecho Público, Barcelona, 1996, págs. 639-666.

BIGLINO CAMPOS, Paloma (coord.): La politica europea de las Comunidades Autónomas y su control parlamentario, Tirant lo Blanch, Valencia, 2003.

BILBAO UBILLOS, Juan María: "El control parlamentario de la actuación de los Ejecutivos autonómicos" en La política europea de las Comunidades Autónomas y su control parlamentario, Paloma Biglino Campos (coord.), Tirant lo Blanch, Valencia, 2003, págs. 201-273.

CARMONA CONTRERAS, Ana María: "El "sui generis" control parlamentario de la colaboración entre Comunidades Autónomas. (Análisis de un supuesto especialmente conflictivo: el Protocolo de intenciones en materia televisiva suscrito por los Gobiernos de Andalucía y Extremadura", Revista Vasca de Administración Pública, Herri-Arduralaritzako Euskal Aldizkaria, n. ${ }^{\circ}$ 66, 2003, págs. 255-277.

CHUECA RODRÍGUEZ, R.: "Los mecanismos de gobierno parlamentario en la Comunidad Autónoma de Aragón", en Estudio sistemático de la Ley del Presidente del Gobierno de Aragón (Ley de Aragón 1/1995, de 16 de febrero), F. López Ramón (dir.), Cortes de Aragón, Zaragoza, 1997.

DOMÍNGUEZ AGUDO, María Reyes: «El control parlamentario: algunas consideraciones en torno a la función de control de las Comunidades Autónomas", Revista Jurídica de la Comunidad de Madrid, n. ${ }^{\circ} 11.2001$.

ELVIRA PERALES, Ascensión y GONZÁLEZ AYALA, María Dolores: Nuevos retos del control parlamentario: Comunidades Autónomas y Unión Europea, Tirant lo Blanch, Valencia, 2002. Reseñado por Alicia González Alonso en Revista de Estudios Políticos, n. ${ }^{\circ} 120$, 2003, págs. 386-394.

FERNÁNDEZ MIRALLES, Sebastián: "El control del Gobierno en el Derecho parlamentario valenciano: las comparecencias del President del Consell", Corts. Anuario de Derecho Parlamentario, n. ${ }^{\circ}$ 5, 1998.

GRANADOS CALERO, Francisco: «El control del Ejecutivo por las Cortes Valencianas", Corts. Anuario de Derecho Parlamentario, n. ${ }^{\circ} 4$ extra, 1997.

HERRERO SUAZO, Santiago: «El control por las Cortes Generales de la actividad financiera de las Comunidades Autónomas" en I Jornadas sobre administración Autonómica, Diputación General de Aragón, Zaragoza, 1982, págs. 151-186.

LÓPEZ ULLA, Juan Manuel: «El control a través de las proposiciones no de ley en el Parlamento de Andalucía", en Estudios de Derecho Constitucional: bomenaje al profesor Dr. D. Joaquin Garcia Morillo, Luis López Guerra (coord.), Tirant lo Blanch, Valencia, 2001, págs. 545-568. 
LUCAS MURILLO DE LA CUEVA, Enrique: El Lehendakari. Análisis orgánicofuncional, Civitas, Madrid, 1991.

MOLLINEDO CHOCANO, José Joaquín: «Las peculiaridades del control parlamentario en la Asamblea de Madrid", en Nuevos retos del control parlamentario: Comunidades Autónomas y Unión Europea, Ascensión Elvira Perales y M. ${ }^{a}$ Dolores Gonzáles Ayala (coords.), Tirant lo Blanch, Valencia, 2002, págs. 33-34.

REVIRIEGO PICÓN, Fernando: “Un breve apunte del control del Gobierno en funciones en las comunidades autónomas", en Nuevos retos del control parlamentario: comunidades autónomas y Unión Europea, Ascensión Elvira Perales, M. ${ }^{a}$ Dolores González Ayala (coords.), Tirant lo Blanch, Valencia, 2002, págs. 89- 107.

ROMERO HERNÁNDEZ, Federico: "Los órganos administrativos de los parlamentos autonómicos como instrumentos de control del ejecutivo", IJornadas de Derecho Parlamentario, Congreso de los Diputados, Madrid, 1985, vol. II, págs. 649-660.

RUIZ-RUISEÑO MONTOYA, Francisco M.: "La política europea de las Comunidades Autónomas y su control parlamentario", Revista de estudios políticos, n. ${ }^{\circ} 121$, 2003, págs. 330-335. Es reseña de La política europea de las comunidades autónomas y su control parlamentario, Paloma Biglino Campos (coord.).

SARMIENTO MÉNDEZ, Xosé Antonio: "O control parlamentario das finanzas públicas na Comunidade Autónoma de Galicia", REGAP. Revista Galega de Administración Pública, n. ${ }^{\circ}$ 13, 1996.

VINTRÓ I CASTELLS, Joan: «Peculiaridades del control parlamentario en Cataluña (1980-1999)", en Nuevos retos del control parlamentario: comunidades autónomas y Unión Europea, Tirant lo Blanch, Valencia, 2002, págs. 67-88.

ABSTRACT: Its divided this bibliography on parliamentary oversight into seven sections, in a structure that attempts to include the most relevant aspects of Parliament's powers of scrutiny. Section 1 approaches a General Theory of parliamentary oversight (powers of scrutiny in general, definition under the Constitution, political basis, comparative analysis and historical perspective). Section 2 looks into the granting and removal of Parliament's confidence. Section 3 analyses the typical instruments applied in the context of rationalised Parliamentarianism in the second half of the $20^{\text {th }}$ Century (questions and interpellations). There is a fourth section devoted to an analysis of published works regarding inquiry committees, an extremely relevant and interesting instrument of parliamentary oversight today. The following section deals with bearings and requests for information and documents. Section 6 focuses on an analysis of the specificities of powers of scrutiny when dealing with sensitive material such as official secrets, secret funds or foreign and defence policy. Finally, in Section 7 we have looked into the particular features of parliamentary scrutiny in the Autonomous Regions. 